\title{
Rations, coexistence, and the colonisation of Aboriginal labour in the South Australian pastoral industry, 1860-1911
}

\author{
Robert Foster
}

\section{Introduction}

By the close of the nineteenth century Aboriginal people were the principal source of labour in the South Australian pastoral industry. The value of their labour derived from the unique type of relationship that developed between Europeans and Aborigines on pastoral stations. This paper examines the contribution of two hitherto neglected aspects of government policy in the shaping of these relationships: the systematic distribution of rations, and the protection of Aboriginal customary rights on pastoral lands. That pastoralists considered these factors significant is demonstrated in the final section, which examines how they successfully resisted government attempts to regulate the employment of Aboriginal people and disturb the status quo.

\section{The significance of Aboriginal labour}

When the colony of South Australia was planned, the possibility that Aboriginal people might be a significant source of labour was never seriously contemplated. It was, after all, a colony based on Wakefieldian principles where labour would be imported along with capital. ${ }^{1}$ It was Aboriginal land that the colonists wanted; if Aboriginal labour proved valuable, then this was a bonus, but it was not an expectation. ${ }^{2}$ There was, however, an expectation that Aborigines would learn 'habits of useful industry'. Children at the Native Schools in Adelaide were given vocational training, with boys taught agricultural skills and girls instructed in the domestic arts. Some attempts were made to put young men trained at the schools into apprenticeships, and girls into service, but most found the isolation unappealing and preferred to return to their communities. These early attempts at 'training' Aboriginal people had more symbolic than practical worth. ${ }^{3}$

1. E Richards, 1986. 'The Peopling of South Australia 1836-1986', in E Richards (ed.), The Flinders history of South Australia. Social history. Adelaide, pp 115-17.

2. Peggy Brock, 1995. 'Pastoral stations and reserves in South and central Australia, 1850s$1950 s^{\prime}$, in Ann McGrath and Kay Saunders with Jackie Huggins (eds), Aboriginal workers. Sydney, $\mathrm{P} 102$.

3. R Foster, 1993. An imaginary dominion. The representation and treatment of Aborigines in South Australia, 1834-1911, PhD thesis, University of Adelaide, p 141. 
The first serious engagement of Aboriginal people in the colonial economy occurred during the Victorian gold rush of the early 1850 s when a massive labour exodus created an unexpected demand for Aboriginal labour. Where pastoralists had been driving Aboriginal people off their runs, they now offered them good rations and sometimes even wages, if they would shepherd their sheep. For a period of time during the 1850 s many pastoralists, particularly in the southern parts of the colony, were heavily reliant on Aboriginal labour. ${ }^{4}$ By the end of the 1850s, as European labour returned and fencing reduced the demand for shepherds, the need for Aboriginal labour diminished. Henceforth, the significance of Aboriginal labour in the southern settled districts was marginal; not only were their numbers small, but they competed with a much larger pool of European workers.

The story was very different in the north and west of the colony. In these areas, where European labour was more difficult to attract and the economic viability of the industry was more marginal, Aboriginal labour grew steadily more important until, by the 1890s, most observers agreed that it had become essential. In 1891 a government inquiry was held into the best ways to develop the colony's pastoral lands. While the issue of Aboriginal labour was not central to the investigation, a number of central Australian settlers were questioned on the matter. A station manager from the MacDonnell Ranges, asked if the stations could be worked without Aboriginal labour, expressed the general view when he answered 'No; probably not'. When Frank Gillen, a telegraph officer at Alice Springs, was asked a similar question, he replied, 'I do not know what they [the squatters] would have done without them' ${ }^{\prime}$

Similar views were expressed by witnesses before the 1899 Select Committee inquiry into a proposed Aborigines Bill. Christopher Wade, a sheep farmer of Strangways Springs, suggested that the pastoral industry in the 'outside districts' would have to be abandoned if the Aborigines 'died out' - unless 'coloured immigration' was introduced. ${ }^{7}$ In the more temperate climate of the south, with its larger pool of white labour, settlers could forgo Aboriginal services and skills, but this was not the case in the 'outside districts'. Despite the early unwillingness of some, relationships between Aboriginal communities and pastoral stations became the rule, largely because the relationship offered squatters a source of labour that suited the conditions of the industry.

\section{The characteristics of Aboriginal employment}

In 1892, Sub-Protector Besley noted that in the northern districts most cattle and sheep stations employed 'from one to a dozen' Aborigines, some of whom were paid 'from 10/- to 25/- per week' with which they bought food, clothing and tobacco for their relatives and friends on the station. ${ }^{8}$ In 1899, the pastoralist Alfred Giles described what he said was the usual arrangement on most pastoral stations in the north:

4. R Foster, 1989. 'Feasts of the full moon: the distribution of rations to Aborigines in South Australia: 1836-1861'. Aboriginal History 13(1): 71.

5. Report of the Pastoral Lands Commission, together with Minutes of Proceedings, Evidence and Appendices. South Australian Parliamentary Papers no. 33 of 1891, p. 112.

6. Ibid., p. 125.

7. Report of the Select Committee of the Legislative Council on the Aborigines Bill, together with minutes of Proceedings. South Australian Parliamentary Papers, nos $77 \& 77$ a of 1899, p. 16. 
All stations employed a number of blackboys, varying perhaps from three to a dozen, and there are few of such stations where a small tribe of the unemployed are not permitted to encamp - these mostly consisting of the wives and relatives of the employed boys. The numbers of these unemployed vary considerably. Today there may be a dozen, to-morrow fifty or one hundred. 9

In 1901, the issuer of rations at Anna Creek reported that there were eighty-five able-bodied Aboriginal people on the station of whom twenty were 'constantly employed and found useful as boundary riders, \&c.', seventeen were 'old and infirm' and fifteen were children. ${ }^{10}$ While the numbers varied considerably from station to station, the pattern was broadly repeated; a core of people in relatively constant employment, together with a camp of relatives who provided the station with a ready source of labour for a variety of other station tasks. ${ }^{11}$ When not in employment, those in the. station camp secured a subsistence from a mixture of sources: food provided by those in work, government rations if they were available, and traditional bush foods.

In 1899 , the pastoralist John Hogarth described the ways in which Aborigines were employed on his property. 'A number', he said, were employed all year round as stockmen and boundary riders and, although paid at a lesser rate than their white equivalents, they received more rations. Others on the station were employed putting up fences, while at shearing time, twenty five to thirty were employed, including women who helped 'at wool scouring and such like'. ${ }^{12}$ Task-oriented work was a common source of employment on stations. In the 1890s, vermin destruction was a task often carried out by Aborigines. In 1895, for instance, Hogarth reported that Aborigines on the station were paid 3d per rabbit scalp. ${ }^{13}$ Early in the following year Robert Bruce at Coondambo reported that in the months of November and December he had paid out $£ 104$ for rabbit scalps, and added that the Aborigines there were also 'first class wild dog destroyers'. ${ }^{14}$ The station's need for labour varied seasonally and according to circumstances, as Hogarth put it, 'he might require twenty blacks at one time, thirty at another, forty at another, and so on'. ${ }^{15}$ The presence of camps on pastoral properties provided station managers with a labour pool that could be drawn upon as needed.

The employment of Aborigines in the pastoral industry has often been described as slavery. ${ }^{16}$ In 1992, Bill Thorpe offered a more sophisticated analysis, suggesting that

8. Aborigines Department, Correspondence files, GRG 52/1/1892/106, 25 March 1892. While there are numerous references to Aboriginal people being paid wages, cash would rarely have changed hands. Instead employees would have drawn against their 'wages' to purchase goods from the station store. This is evident, for instance, in the ledger books of Murnpeowie Station during the 1890s. Beltana Pastoral Company, Mortlock Library of South Australiana, BRG $133 / 36$.

9. South Australian Register, 20 December 1899.

10. Report of the Protector of Aborigines for the Year Ending June 30, 1901, Adelaide, 1901, p. 6.

11. Brock in McGrath et. al., 1995: 107; Ann McGrath, 1987. 'Born in the cattle', Aborigines in the cattle country. Sydney, pp. 27-32.

12. Report of the 1899 Select Committee, p. 70 .

13. GRG 52/1/1895/120, 25 March 1895.

14. GRG 52/1/1896/55, 20 February 1896.

15. Report of the 1899 Select Committee, p. 70.

16. B Thorpe, 1992. 'Aboriginal employment and unemployment: colonised labour', in C William and B Thorpe, Beyond industrial sociology: the work of men and women. Sydney, P. 96. 
it was 'a related but distinct form' of slavery, which he termed 'colonised labour'. ${ }^{17}$ In the first instance, writes Thorpe, colonised labour derives from the seizure of a territory and its people by a major power ... in order to dominate and exploit the colonised territory and its people economically, politically and culturally'. Secondly, colonised labour is 'subordinate to all other forms of labour'. Thirdly, the colonial relationship, 'like slavery, is suffused with force'. Fourthly, and most importantly, 'the colonised worker is both desirable and undesirable'. This is in sharp contrast to 'the slave worker' who 'is always valued for his or her labour':

The value of slave labour to the slave owner is such that, firstly it comprises an 'investment of capital in human resources' (Saunders 1982: xvii) and, secondly, it is constantly employed. ${ }^{18}$

In contrast, the colonised worker 'is alternately valued as a labour commodity but also devalued, employed and unemployed, paid but mostly unpaid, integrated but mostly marginalised'. ${ }^{19}$ This is an eminently appropriate description of the unique character of Aboriginal employment in the pastoral industry. In South Australia, the emergence of this sort of Iabour relationship was facilitated by the practice of distributing rations, and the fact of Aboriginal rights on pastoral lands.

\section{The systematic distribution of rations}

In the early years of settlement the government regularly gave out items of food and clothing to the Aborigines as demonstrations of good faith, rewards for good conduct, and inducements to adopt European ways. During the 1840 s, as settlement spread and violence became commonplace in frontier districts, the practice of distributing rations was systematised. ${ }^{20}$ As new districts opened up, the government would begin distributing rations - usually at a police station - with the aim of gaining some control over the local Aboriginal population. The rations were regarded as a form of compensation, replacing the subsistence that European occupation was progressively denying the Aborigines and, theoretically, removing the temptation for them to attack European stock and property. We see the rationale articulated in 1852 in discussions concerning the establishment of a depot in the north. Following a series of attacks on Hayward's station near Lake Torrens, the Protector wrote:

This appears to be the time for establishing the feeding station for the North. The settlers are all short of men to attend their flocks \& the Natives are quite aware of the fact \& much disposed to take advantage of it. The feeding station would be a means of keeping them quiet. ${ }^{21}$

A depot was established early in the following year and the newly appointed SubProtector was instructed to induce the wild natives from the hills to live at his station, and by keeping them some time in contact with himself and the police, so far civilize them, as to render them not only harmless but useful to the settlers' ${ }^{\prime 2}$ As this example

17. Ibid.

18. Ibid.: 98 .

19. Ibid.: 99 .

20. The system of distributing rations to Aboriginal people in South Australia in the period up to 1861 is discussed at length in Foster, 1989.

21. Cited in Foster, 1989, p. 70.

22. Ibid., pp. 70-71. 
shows, it was hoped that the system would not only concentrate local Aboriginal populations, but would also facilitate surveillance.

With the advent of responsible government in 1856 interest in Aboriginal welfare plummeted and the post of Protector - a Colonial Office creation - was abolished. For the next few years the distribution of rations remained one of the few administrative manifestations of government interest in Aboriginal welfare. By 1860, however, community concern over the increasingly parlous condition of Aboriginal people, especially in the settled districts, led to the establishment of a Select Committee to inquire into their condition. ${ }^{23}$ The inquiry found that the government had been negligent in its administration of Aboriginal people and that, at the very least, it had a responsibility to provide for their physical and material wellbeing. The Commissioners made a variety of recommendations regarding health, education, legal status and general welfare, but the only tangible outcomes of the inquiry were the re-establishment of the Protector's Office and a substantial reorganisation of the system of distributing rations. ${ }^{24}$

\section{Reorganisation after 1861}

In 1861 Dr John Walker was appointed the new Protector of Aborigines. The appointment of a medical practitioner reflected the generally pessimistic tone of the Select Committee's report which was underpinned by a belief that the Aborigines were'dying out'. Following a tour of inspection in 1863, Walker submitted a report on the general condition of the Aborigines in which he made a number of recommendations. While he believed that in most cases the Aborigines were generally well supplied with food, there were cases where people were in great want. 'Sometimes', he suggested, 'the season or state of the weather' made fishing and hunting difficult, 'sickness or disability' made it difficult for people to provide for themselves, and dependants such as the elderly and young children suffered when their families could not provide for them. It was for these cases, he wrote:

that feeding depots have been formed, and unquestionably much good has resulted from their establishment, but the number of them is insufficient for the requirements of the Aborigines throughout the colony. ${ }^{25}$

It was on the basis of this assessment that Walker recommended the establishment of new depots throughout the colony.

Before Walker's appointment there were 14 ration depots in the colony; six years later (in 1867) there were 58 . Over the next 50 years the number of depots gradually declined, but there were always more than 40 depots. ${ }^{26}$ What was put into place was a

23. Foster 1993: 177-79.

24. Ibid.: 185-87.

25. Crown Lands and Immigration Office, Correspondence files, GRG 35/1/791/1863, 9 March 1863.

26. These figures come from a variety of sources. The reports of the Protector of Aborigines. South Australian Government Gazette (SAGG): 11 July 1867, p 665; 20 August 1868, p 1148; 20 August 1874, p 1671; 18 March 1875, p 516; 20 March 1879, p 798; 12 February 1880, p 548. Protector's Annual Report in the correspondence files of the Aborigines Department: GRG 52/1/1884/ 313; GRG 52/1/1886/305; GRG 52/1/1894/406; GRG 52/1/1898/396. Ration ledger book, 1909-1927 GRG 52/25. For maps showing the spread of depots in the period up to 1915, see Griffin and McCaskill 1986: 31. 


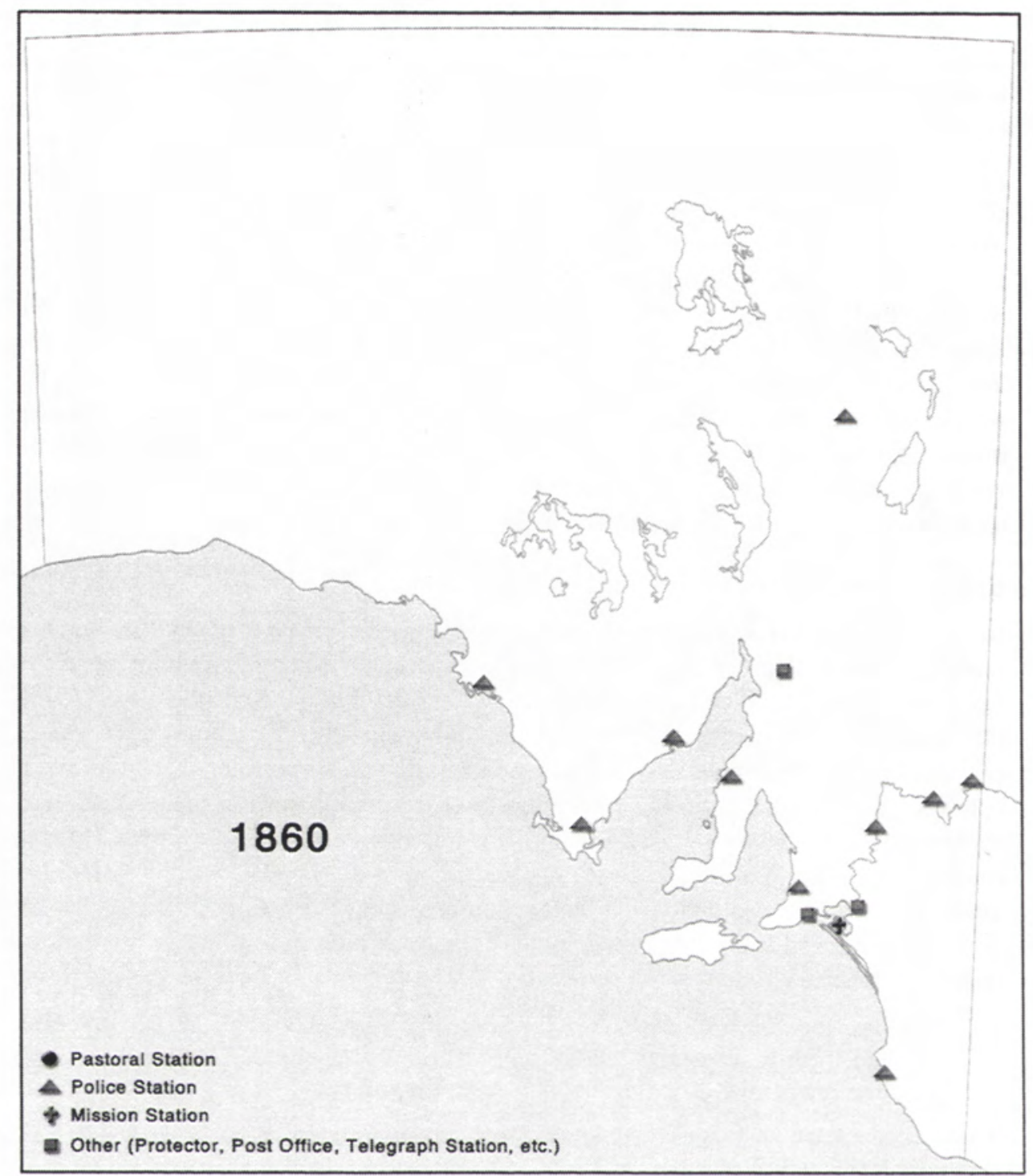

Map 1 Southern South Australia, 1860 


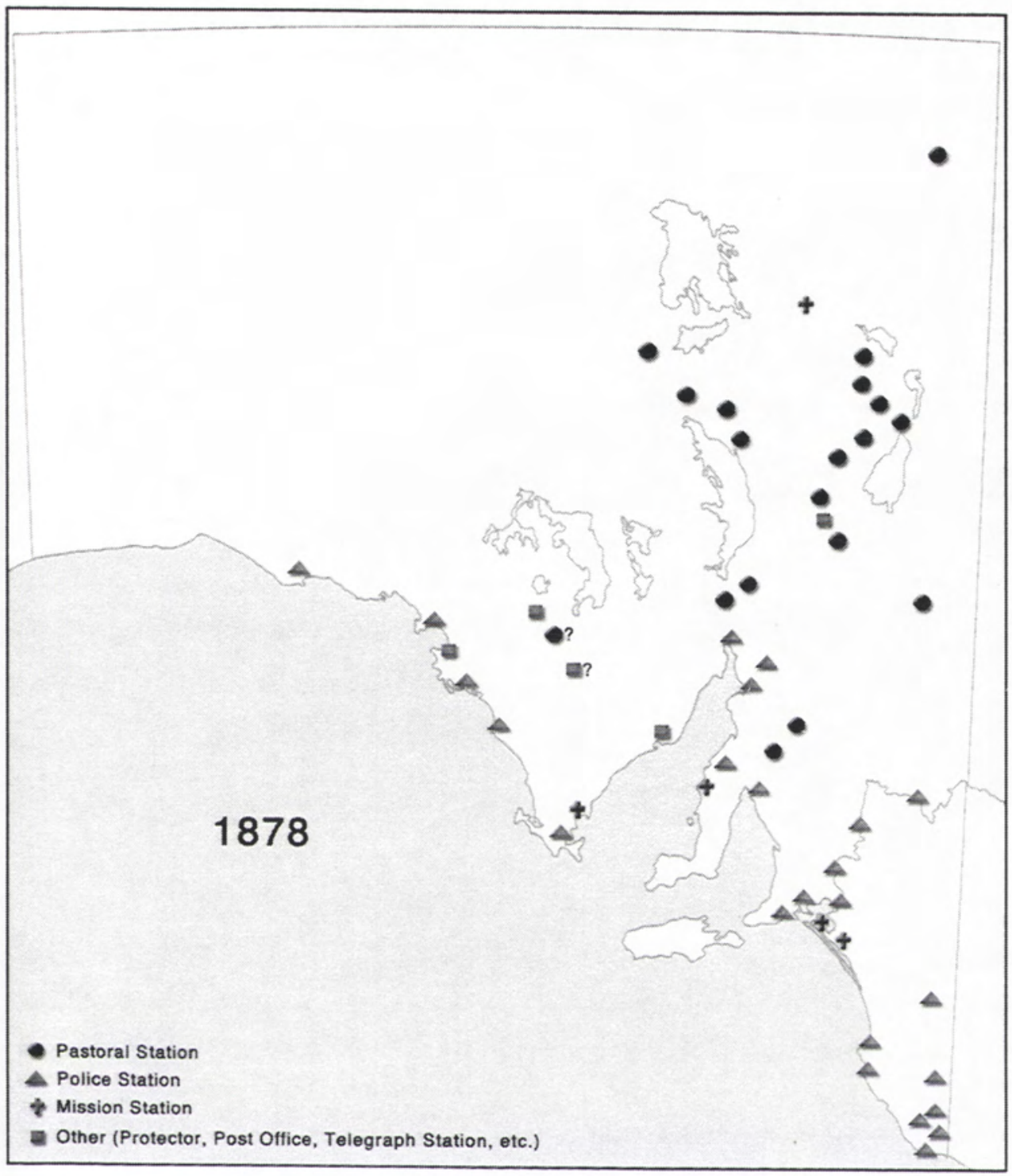

Map 2 Southern South Australia, 1878 


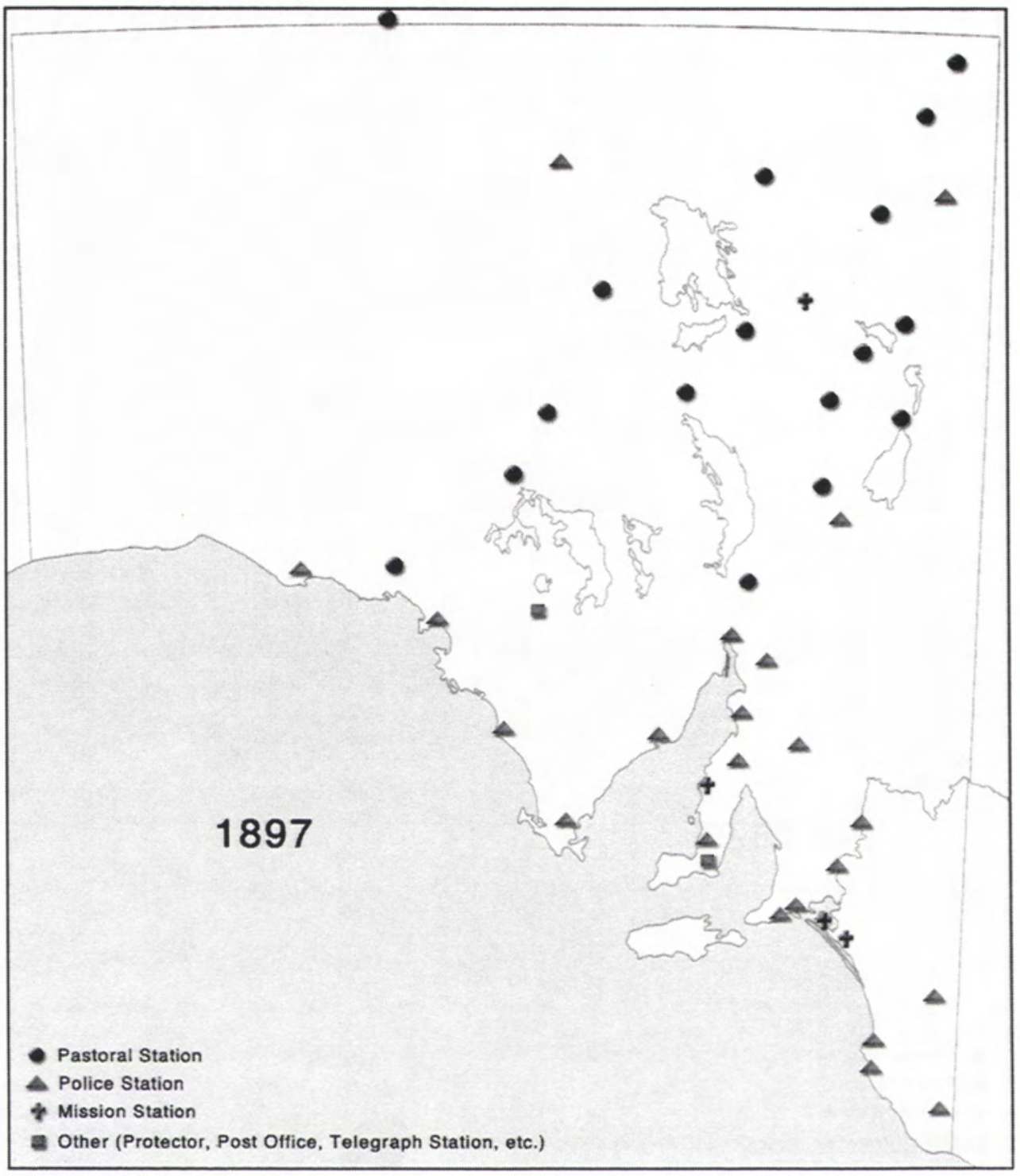

Map 3 Southern South Australia, 1897 


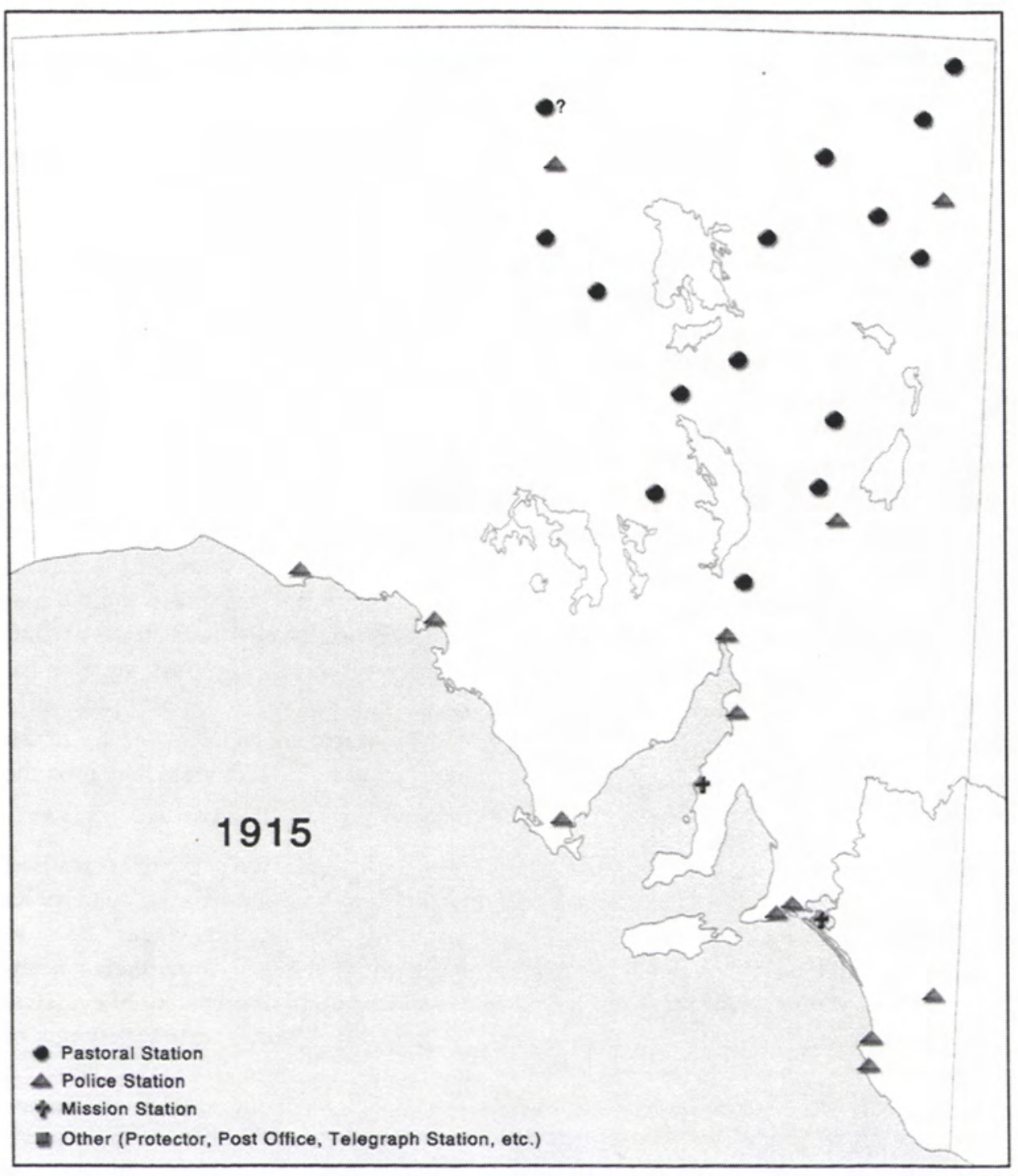

Map 4 Southern South Australia, 1915 
rudimentary social welfare system that, it was envisaged, would provide Aborigines with the basic necessities of life until such support was no longer needed. That is to say, until they found their niche in the colonial economy, or 'died out'.

While the policy was developed largely in response to the condition of people in the southern settled districts, it was also extended to the northern and western pastoral districts. As had been the case before 1860, most of the ration depots in the south were police stations (Map 1). One of the most significant features of the new system was that in the outlying districts managers of pastoral stations became the usual issuers of rations. In 1867 about a third of the 58 depots throughout the colony were pastoral stations, and almost all of these were in the northern and western pastoral districts. ${ }^{27}$. The contrast between 'north and south' was even more stark in 1897 (Map 3). Of the 48 depots in operation, more than half were in the northern pastoral districts, and 18 of these were under the control of station managers. Of those in the southern districts, all but a few were located at police stations. ${ }^{28}$ The pattern continued into the early part of the twentieth century, the overall number in the south, usually under the control of the police, gradually dwindling, while the numbers in the north, mostly under the control of station managers, remaining relatively stable (Map 4). ${ }^{29}$ It is important to note that the settlers selected were those in the 'outlying' districts, essentially the districts beyond Goyder's 'line of rainfall', which marked the boundary between country suitable for agriculture, and that suitable only for pastoral activities. ${ }^{30}$ Given that part of the early rationale of the system had been to remove Aboriginal populations from the runs of the settlers and give the police some measure of control over them, why were they now the favoured sites for depots in the pastoral districts?

The report of the 1860 Select Committee advised against the 'evils' of centralised depots and recommended that in the outlying districts 'well-intentioned' settlers be given the task of distributing rations. By decentralising distributions it was hoped to keep Aboriginal people, as much as possible, in their own districts, rather than concentrating them in towns and settlements. ${ }^{31}$ These recommendations arose out of evidence given at the inquiry. A number of witnesses, for instance, commented on the value of Aboriginal labour, and observed that good relationships had been established between Aborigines and settlers on many pastoral runs. ${ }^{32}$ Questioned about whether or not pastoralists would undertake the task of issuing rations, it was suggested they would, although uncertainty was expressed about the consequences, especially whether or not too many would be attracted to the stations that issued rations. It is interesting to note that the matter of Aboriginal access rights on pastoral lands was also discussed in reference to the question of rations. ${ }^{33}$

27. SAGG, 11 July 1867, p. 665.

28. GRG 52/1/1898/396.

29. It should be noted that while the overall number of depots remained stable, their locations did not. While there was a core of stations that usually issued government rations, depots were established and disbanded as circumstances - the establishment of new stations, the closure of existing ones - required, or in response to emergencies such as localised droughts.

30. T Griffin \& M. McCaskill, 1986, P. 16

31. Report of the Select Committee of the Legislative Council upon the Aborigines, South Australian Parliamentary Debates, no. 165 of $1860, \mathrm{p} 4$.

32. Ibid.: 4, 9-12, 19. 
The Select Committee inquiry shows that the government was well aware of Aboriginal people's access rights on pastoral lands. Given this predicate, the distribution of rations at pastoral stations was a cheap and logical means by which the government could avoid the 'evils' of centralised distribution and keep Aboriginal people in their own districts. Furthermore, the policy would virtually ensure that relationships would develop between Aboriginal people and the pastoralists who gave out the rations; a potential benefit of this would be to draw Aboriginal people into the pastoral industry.

\section{The ration scale}

When the government began to issue rations in the 1840s, they were issued to all-comers once a month - the rations being 4 pounds of flour per adult with half that for children, together with an annual distribution of blankets. ${ }^{34}$ During the $1850 \mathrm{~s}$, when Aboriginal labour was vital, the issue was restricted to the sick and the infirm. ${ }^{35}$ Instructions given to the issuers of rations in October 1859 entrenched this principle, directing them to give rations only to 'the sick, the old, the infirm, orphan children and women with infants under twelve years old' ${ }^{36}$ The able-bodied were not to be given rations if it was believed that they could obtain work, or subsist by fishing and hunting. While this was the principle, and continued to be so well into the twentieth century, no one had any doubt that the rations were shared among the relatives of those who received them.

The daily food ration was 1 pound of flour, 2 ounces of sugar and half and ounce of tea, with the issues being made once a week. Why these rations and why this scale? The answer seems to lie in the working man's ration that became standardised by the early nineteenth century. According to Michael Symons in his book One continuous picnic: a history of eating in Australia, 'The itinerant workforce ... were paid in rations. Handed out on Saturday nights in unreliable measures and supplemented by spirits and a final cheque, their food earned the name, 'Ten, ten, two \& a Quarter', that is $10 \mathrm{lb}$ flour, 10lb meat, $2 \mathrm{lb}$ of sugar; $1 / 4 \mathrm{lb}$ tea' ${ }^{37}$ The items and the scale were similar to the rations issued to Aborigines by the government, with the obvious difference that there was no meat. The absence of meat is explained by the fact that flour, tea and sugar could be transported over large distances without spoiling, while meat could not be. ${ }^{38}$

Symons points out that the basic meal made from these working man's rations was 'a damper, a fry of meat and pots of tea':

The damper was flour and water, without leavening. The meat was salted pork, corned beef and then slaughtered mutton cooked without aging. The tea, though taken with plenty of sugar, generally lacked the refinement of milk. ${ }^{39}$

33. Ibid: 9-18, 44-50. These points were raised in the evidence of Major Warburton, the Commission of Police, and by JT Bagot, the newly appointed Commissioner of Crown Lands.

34. Foster 1989: 69.

35. Ibid.: $76-77$.

36. Report of the 1860 Select Committee, appendix, $p$ ii.

37. Michael Symons, 1982. One continuous picnic: a history of eating in Australia. Adelaide, p 27.

38. Flour could, of course, 'go off' and sugar could turn into the equivalent of rock candy, but as a rule they were transportable and had a relatively long shelf life.

39. Symons 1982: 28. 
This was the basic diet for breakfast, Iunch and dinner. By the mid-nineteenth century this was probably also the basic diet of Aboriginal people who became reliant on government rations - supplemented by native game and plant foods.

In addition to the staple of flour, sugar and tea, other items of food were issued on an occasional basis - usually as medical comforts. Rice, Walker instructed, was not to be part of the ordinary issue, but given only as a medical comfort - issued in place of flour and with a doubling of the sugar ration. Sago was also issued occasionally on the same principle. Meat could be given as a medical comfort but required the authorisation of a medical practitioner. ${ }^{40}$ Though not issued in Walker's time, tobacco later became a regular ration item. Instructions to issuers in 1878 indicated that tobacco was to be considered a 'regular' ration but given out only as a reward to the able-bodied for good conduct or service, or as a comfort for the aged and infirm. ${ }^{41}$

\section{The dependency dilemma}

The distribution of rations provided the government with a dilemma. The system was revamped and expanded because it was apparent that people were starving - the occupation of the country by pastoralists making it impossible for Aborigines to survive entirely on traditional resources. Yet at the same time the government had no desire to make Aboriginal people dependent on rations, and it wanted to encourage them into the colonial economy. Protector Hamilton summed up the situation in one of his reports for 1875 :

Their hunting grounds are now greatly diminished as agricultural settlement progresses, thus depriving them of their natural food. Another circumstance is ... that, except at certain times of the year, such as shearing time, the Aborigines experience great difficulty finding employment. As runs become fenced their services appear to be less in demand, and their peculiar habits of life unfit them for a sudden change to the heavy and continuous work of ordinary labourers.

The system now in force for the protection and support of the natives has been in operation about fifteen years; its merits and failings have therefore been tested by experience.

In ministering to their physical necessities and alleviating the hardships of their position it has accomplished a good deal, but it seems to have failed in checking the high rate of mortality ...

The practice of supplying food and clothing, except in exchange for an equivalent in labour, is objectionable in its tendency to pauperise by leading to improvident habits and indolence. ${ }^{42}$

The basic ration of flour, sugar and tea was at best a starvation diet. As the local issuer of rations at Tarpeena reported in the winter of 1868, 'when they have no flesh to eat one pound of flour is not sufficient nourishment for one day for any man or woman, particularly when the weather is cold'.$^{43}$ The Aboriginal custom of sharing the rations among one's relatives, regardless of age or infirmity, meant that in practice the issues

40. Crown Lands and Immigration Office, Correspondence files, GRG 35/1/791/1863, 9 March 1863.

41. South Australian Government Gazette, 20 March 1879, p 797.

42. Ibid., 18 March 1875, p 506.

43. Ibid., 20 August 1868, p 1145. 
were even more parsimonious than the figures, on the surface, indicated. The government never intended it to be more than a supplement, or a safety net. The instructions issued in 1859 stated that rations were not to be given to 'able-bodied natives if there is reason to believe they can get work or can obtain their subsistence by fishing or hunting' ${ }^{44}$ Protector Walker, as has already been noted, reiterated the principle when he reorganised the system of ration distributions in 1863. The expectation that Aboriginal people would continue to rely on traditional resources to supplement or replace paid employment is a crucial point. In the pastoral districts, it was predicated on their right to live traditionally on pastoral lands. What emerged was a subsistence strategy based on maintaining an equilibrium between paid employment, traditional resources and rations. ${ }^{45}$

\section{Aboriginal rights on pastoral lands}

On 1 July 1851 fourteen-year pastoral leases came into operation in South Australia, replacing the previous system of issuing annual licenses. ${ }^{46}$ When acceding to this system in New South Wales a few years before, the Colonial Office endeavoured to ensure that Aboriginal rights were not unduly injured. In a Dispatch to Governor Fitzroy, Earl Grey wrote:

I think it essential that it should be generally understood that leases granted for this purpose give the grantees only an exclusive right of pasturage for their cattle, and of cultivating such Land as they may require within the large limits thus assigned to them; but that these Leases are not intended to deprive the natives of their former right to hunt over these Districts, or to wander over them in search of subsistence, in the manner to which they have been heretofore accustomed, from the spontaneous produce of the soil, except over land actually cultivated or fenced in for that purpose. ${ }^{47}$

Acting on instructions from the Colonial Office, Lieutenant Governor Young ensured that South Australian pastoral leases had extensive clauses ensuring the protection of Aboriginal rights. The leases gave Aboriginal people unimpeded access to pastoral lands, including 'springs and surface waters'. It ensured their 'unobstructed right' to 'use occupy dwell on and obtain food and water' as well as to:

make and erect such wurlies and other dwellings as they have been heretofore been accustomed to make and erect and to take and use for food birds and animals ferae naturae in such a manner as they would have been entitled to do if this demise had not been made. ${ }^{48}$

It was made clear that if the lessee should 'break or infringe any of the covenants reservations exceptions conditions provisions or agreements ... the demise hereby made and the term hereby grants shall cease determine and be void' ${ }^{49}$ In essence, these

44. Report of the 1860 Select Committee, appendix, $p$ ii

45. A similar situation applied in the southern districts, but the more intense nature of settlement rapidly reduced the availability of, and access to, traditional resources.

46. Peter Donovan, 1995. 'In the interest of the county'. a history of the Pastoral Board of South Australia 1893-1993. Openbook Publishers, Adelaide, pp 8-9.

47. Grey to Fitzroy, 11 February 1848, Historical Records of Australia, Series I, vol. XXVI, p 224.

48. Lease of Waste Land of the Crown of Michael Martin and John Bradford, South Australian Department of Lands, Pastoral Lease no. 226, 1 July 1951, p 1. 
provisions guaranteed those Aboriginal people whose country was occupied by pastoral leases, the right to continue living on their land in such a manner as they would have been entitled to do' if the lease had not been granted, provided they did not interfere with the stock or property.

When the form of the pastoral lease was being worked out in 1851 there was relatively little public discussion regarding the clauses protecting Aboriginal rights. What there was related to the feasibility of coexistence. Archdeacon Matthew Hale, who had recently established the mission at Poonindie, pointed out that some Aboriginal forms of land use were 'diametrically opposed to the interests of the white occupiers of the country'. ${ }^{50}$ While he did not oppose the clauses, he was concerned that the rights of both parties were clearly spelled out. The Commissioner of Crown Lands, Charles Bonney, who was drafting the clauses under the direction of the Lieutenant-Governor, expressed similar concerns. On 3 June 1851, he wrote to the Colonial Secretary regarding a letter from a settler who raised objections to the proposed reservations. Bonney observed: 'There is undoubtedly a difficulty in making such reservations ... when the customs of the natives are directly at variance with the purposes for which the country is occupied by the holders of the runs'. ${ }^{51}$ Bonney argued that 'the only mode of meeting this difficulty that $I$ can suggest is to compensate the natives for what they lose by any restrictions which it may be found necessary to impose upon them'. He went on to suggest that supplies of 'provisions and clothing' might be provided to Aboriginal people at regular intervals as compensation for them being deprived of 'their means of securing food'. The Lieutenant-Governor, however, held his ground and a few weeks later Bonney was defending the reservation clauses in a report on the subject of Archdeacon Hale's letter. Explaining the motives for the insertion of these new provisions, Bonney wrote:

With regard to the difficulty pointed out by Mr Hale in reconciling some of the customs of the natives with the interests of the occupiers of runs, I am aware that in the Port Lincoln district this difficulty may arise. But whether it may be found expedient or not to allow the full exercise of these privileges, I think such reservations should be inserted in the leases as will give the Government complete control in the matter.

I am of opinion that the knowledge that the Government is in possession of this power and that the runs are liable to be resumed for the use of the natives, will be sufficient to ensure the forbearance of the white people, and to render them rather desirous of conciliating the natives in order that no necessity may arise for the exercise of these powers. ${ }^{52}$

The reservation clauses were in all pastoral leases issued after 1 July 1851, but was any notice taken of them? Given that they were an imposition of the British Colonial Office did they become a dead letter?

49. Ibid.

50. Colonial Secretary's Office, Correspondence files, State Records, GRG 24/6/1851/1581, 9 May 1851.

51. GRG 24/6/1851/1662, 3 June 1851.

52. GRG 24/6/1851/1885, 24 June 1851. 
The pastoralists could have been expected to regard the new leases, with their clauses guaranteeing coexistence, with some hostility, but they were received with hardly a murmur. The likely reason for this is that their introduction coincided with the gold rush, and the accompanying exodus of European labour. At the very time that Aboriginal rights on pastoral lands were enshrined in the leases, the pastoralists - desperate for labour - were inviting Aboriginal people onto their land. While they may have regarded the conditions of their leases as an imposition, the coincidental benefit of Aboriginal labour gave them no reason to oppose the conditions.

While no leases were ever forfeited on the grounds that Aboriginal rights were infringed, the government did occasionally remind individual pastoralists of the conditions of their lease. In 1876, for instance, missionary Meyer, at Kopperamanna, complained to the government that $\mathrm{Mr}$ Lewis of Cowarie Station was driving Aborigines off his run. At Meyer's suggestion, the pastoralist was reminded of the conditions of his lease. Lewis claimed that the allegations were 'utterly false', adding, 'the blacks are now camped at sundry places on the run unmolested by me or anyone on the place'. ${ }^{53}$ There is no evidence to either confirm or refute the missionaries' allegations, but it is significant that Cowarie Station later became a ration depot. Over the course of the nineteenth century there were very few recorded disputes regarding Aboriginal rights on pastoral leases. A reasonable interpretation might be that this was because the rights were generally ignored. However, a closer examination of the evidence suggests another interpretation, that many pastoralists respected Aboriginal access rights because they were beneficial to them.

\section{The impact of European pastoralism on Aboriginal subsistence}

Despite the fact that Aboriginal people continued to have rights on pastoral lands, European occupation of key water sources, combined with the stocking of the country, severely reduced their ability to support themselves from traditional resources. This process can be seen in especially stark relief during drought years. In 1864, for instance, a drought set in that lasted four years. The drought, combined with the overstocking of the country, had a devastating impact on the Adnyamathanha people of the Flinders Ranges. Writing from Yudnamutana in the northern Flinders Ranges the pastoralist JB Hughes graphically described the impact of the drought:

In ordinary years the natives have an ample supply of food in the numerous animals indigenous to the country. This year the terrible drought has been fatal to those animals as it has been to the sheep and cattle of the squatters. Wallabies, euros and kangaroos are lying dead in all directions. Those that remain are so reduced in number that they have become a rarity in districts that generally teemed with them ... they no longer afford the natives the supply of animal food on which they heretofore depended. As blackfellows have pathetically told me, 'Euro no food now - big one tumble down ...'

The natural severity of the drought is greatly aggravated by the flocks and herds of the squatters which have utterly consumed or trodden out every vestige of grass or feed within miles of water. The aborigines have therefore but two 
resources - they are compelled to crowd around the dwellings of the squatters and

beg for food, or to ... prey upon the flocks and herds. ${ }^{54}$

As the Protector noted of the Northern Districts in 1867, 'the almost total absence of native animals, and the failure of other resources' had placed 'a very large number of Aborigines in most trying circumstances, and dependent upon the generosity of the government. ${ }^{55}$

During another drought in 1884, Nathaniel Phillipson, the owner of the Cordillo Downs Station, requested government rations. Now that the country was stocked, he wrote, it was nearly destitute of kangaroos and emus and, because of the drought, there were no vegetables to fall back on, 'the stock having destroyed everything in the vicinity of the waters'. As a consequence, the Aborigines were in a starving condition but, because there were so many, the station could not afford to support them. Recommending Phillipson's request, the Sub-Protector in the district pointed out that there were 190 on the station, 100 able-bodied adults and children and 90 old, sick or infirm. $\mathrm{He}$ observed that they did well in good seasons, but suffered badly during droughts. The able-bodied, he pointed out, had enough trouble obtaining food for themselves, and consequently the people dependent on them suffered. ${ }^{56}$

The correspondence files of the Protector's Office contain abundant testimony of Aboriginal dependence on rations, usually articulated when depots were closed or shifted. In 1897 the issuer at Mount Serle wrote to the Protector complaining that the Aborigines at the depot were 'bold and threatening' and refused employment rabbit hunting at the pay scale he offered. To teach them a lesson, he wrote, he was going to suspend the issue of rations for a month. The Protector sought the advice of a local government official and was told that the issuer was new to the district and did not understand the situation. The Aborigines, he reported, were experiencing a hard time during the drought, there was very little work for them and they had become dependent on government rations. ${ }^{57}$

The nature of the rations themselves was also important. A couple of years earlier at the same station, the issuer complained that while he had plenty of flour, he had 'no sugar or tea, please forward tea \& sugar [and] tobacco to serve out with the flour'. He underscored his request by heavily underlining his plea. It was no use, he added, 'telling them I have no tea \& sugar, they expect their usual ration every week'. ${ }^{8}$ The point here is that the rations were important not only because they were a supplemental source of food, but because they were desirable commodities - literally, attractive and addictive.

\section{The significance of government rations to European pastoralists}

In his report for September 1868, the Protector noted that settlers were disappointed when the government refused to give them rations to distribute, adding 'great jealousy exists between those who have Aboriginal depots and those who have not, and 1 am

\footnotetext{
54. Cited in Dorothy Tunbridge, 1991. The story of the Flinders Ranges mammals, Sydney, p 21.

55. SAGG, 11 July 1867, $\mathrm{p} 665$.

56. GRG 52/1/1885/10, November 1884 .

57. GRG 52/1/1898/15, 21 December 1897 \& 5 February 1898.

58. GRG 52/1/1896/23, 15 January 1895.
} 
exposed to the charge of partiality when duty renders it necessary for me to refuse compliance ${ }^{\prime 5}$ What then was the advantage of having government rations?

At the simplest level, rations provided pastoralists, who were forbidden by law from driving Aboriginal people from their properties, with the means of controlling them. ${ }^{60}$ In 1888, the overseer at Poonaruna Station, on the Warburton River, requested rations. The trouble, he wrote, was that the Aborigines passed back and forth over his run to get government rations at Cowarie Station. There were over one hundred and fifty individuals in the group and they sometimes killed his cattle for food. The fact that they did this, he added, did not surprise him because they were in 'great straits' as a result of the drought. If he had rations it would be a 'means of keeping them in a central position and near the station, where they would not do so much damage' ${ }^{61}$ From his point of view, it was better that they were near the station where he could keep an eye on them, and where he could provide for them, rather than have them out of sight and killing his stock because of a desperate need for food. The logic of the distributions in this case is very near to that which underpinned the system when it was introduced: provide an alternative subsistence hoping, thereby, to remove the need, through sheer hunger, to attack European stock and property.

While in the case of Poonaruna Station, rations had the negative benefit of neutralising a source of conflict, they also had positive benefits, being used to attract, maintain and control an increasingly valuable source of labour. In August 1898, the owner of Dalhousie Springs wrote to the government asking if he might have rations, claiming that his station was a principal camping place for natives - they come into the Springs and hunt and collect nearby'. He said he fed those who worked, and often those who did not. The police were disinclined to support the request, saying the only ones on the station were those employed as shepherds or in general duties. In another letter they pointed out that the station was worked almost entirely by black labour, there being only two Europeans on the property. A former manager of the station said that the owner refused to allow him to employ whites and that his 'greatest trouble and complaint was the scarcity of blacks upon the run'. A ration depot, the owner believed, would materially assist 'in keeping a few able-bodied blacks about the station' ${ }^{62}$ In other words, even though rations were not distributed to the able-bodied, the fact that they were distributed to their dependents helped attract able-bodied labour to the station.

When the owner of Cootanoorina Station applied for government rations in April 1893 he made no attempt to disguise the economic advantages. He noted that he employed 'a number of black boys' on the station who were paid wages and received station rations, but he wanted the government rations for the eight old men and women on the station. His problem, he wrote, was that it is no use to put Blackboys on a well

59. GRG 52/1/1868/387, 30 September 1868 .

60. Despite the fact that the conditions of their lease made it illegal for them to drive Aboriginal people off their properties, there is no doubt that some pastoralists did drive them off. The evidence is not strong enough to make a judgement about the numbers who abided by the conditions and those who did not.

61. GRG 52/1/1888/320, 18 October 1888 .

62. GRG 52/1/1898/396, 29 August 1898. 
by themselves whilst these old blacks are on the place, for as soon as I send rations out to the boys, they all go out to the well \& eat all the rations in a day or two, consequently the boys instead of doing their work have to go hunting for food until the next rations are sent out'. ${ }^{63}$ If the dependents of the workers were not supplied with rations, the work on the station was likely to suffer.

The police were well aware that government rations were being used to subsidise the cost of Aboriginal labour. In 1905, the Mounted Constable at Innamincka observed, 'depots are not always applied for and worked for the benefit of the Aborigines themselves but often to run a station cheaply on black labour (and Government rations). ${ }^{64}$ As this passage implies, the distinction between government rations and station rations would often have been meaningless. ${ }^{65}$

In their defence, pastoralists often portrayed their relationship with Aborigines as a compassionate, if not philanthropic, one. 'The pastoralists', said John Warren in 1899, 'were the best friends the natives had'; not only did they provide them with employment, but they ensured that the old and infirm did not perish from starvation. ${ }^{66}$ They argued that they were doing the government a favour, and that the task of distributing rations was a burden. They complained that they were often out of pocket when supplies arrived late and they had to draw on their own resources. They resented bureaucrats castigating them for filling out returns incorrectly. ${ }^{67}$ Their most common complaint was the situation they faced during drought years when sometimes hundreds of people would be drawn to their station with the knowledge that government rations were available. Drawing attention to just this circumstance at Coondambo in 1896 , Robert Bruce observed 'there is no thanks and no end of trouble attached to this business' ${ }^{68}$ In 1900, Bruce requested a smaller supply of rations, saying that he did not want to be a permanent depot because it attracted too many to the station. He only wanted enough for the 'old, infirm, and sick, who occasionally visit the locality, the able-bodied being usually employed getting their own living rabbiting, etc. ${ }^{69}$ Bruce's $^{\prime}$ experience suggests that pastoralists were quite capable of 'manipulating' the distributions to manage the numbers on their properties.

Commenting on the relationship between Aborigines and pastoralists in 1899, John Egerton-Warburton described the two groups as 'mutually dependent on one another'. ${ }^{70}$ The changes wrought to the land by European pastoralism made it impossible for Aboriginal people to rely solely on traditional resources, while the marginal nature of the country made it difficult for pastoralists to operate effectively without cheap but efficient Aboriginal labour. The preceding examples highlight why there was 'great jealousy' between those who were given government rations and those who were not - supplying rations to the dependents of those who worked assisted in

63. GRG 52/1/1893/123, 24 April 1893.

64. Cited in H Tolcher, 1986. Drought and deluge. Melbourne, p 138.

65. An effort was made to search pastoral station records to investigate this relationship, but the records in the public domain were too few to make the task meaningful.

66. South Australian Parliamentary Debates, 12 July 1899, p 32.

67. Adelaide Observer, 24 February 1866; 9 August 1884; 23 August 1884; 23 June 1900.

68. GRG 52/1/1896/53, 11 March 1896.

69. Adelaide Observer, 23 June 1900.

70. Ibid., 30 September 1899. 
both securing and maintaining one's workers. Those who had government rations were effectively having the cost of labour subsidised, those who did not had to supply the additional rations out of their own supplies, or risk losing their work force.

\section{The significance of Aboriginal rights on pastoral lands}

In the early years of settlement pastoralists would almost certainly have regarded the presence of Aboriginal people on their land as an imposition. Over time, however, as the value of Aboriginal labour became more and more apparent, the fact that Aborigines had the right to hunt and gather on pastoral lands had positive advantages. At the most fundamental level, it enabled an Aboriginal presence on pastoral properties, thereby securing a source of labour. Furthermore, the fact that Aborigines were not only permitted, but expected, to continue exploiting traditional resources had other advantages. Like government rations, it subsidised the cost of labour. Most importantly, because the people were in their own country, it meant that their services could be engaged or dispensed with at will, without risking their permanent loss.

A report from the issuer of rations at Cowarie Station on Lake Eyre in the summer of $1879-80$ provides a good insight into this aspect of station life. It had been an 'exceptionally good season for the natives', he wrote, they 'have been able to roam all over the country, and obtain an abundant supply of food', which consisted of 'fish, rats, lizards, and 'waddaroo' (a long white root, something like a parsnip), supplemented by four or five different herbs'. While he reported that he was distributing rations to ten or eleven people, most of the fifty or sixty Aborigines there, including the aged and infirm, were 'out on the run', a number which included his stockriders. The Diamantina was in flood, he wrote, 'and some of our black stockriders have deemed it a suitable time to have 'a spell and walk about eat fish', ${ }^{71}$

This account highlights an important feature of station life, that the Aboriginal people associated with stations continued to maintain many features of their traditional life and their traditional association with their country. ${ }^{72}$ It was not uncommon for pastoralists to favourably compare the lives of Aboriginal people on their stations, to the lives of those on missions. Defending pastoralists against claims that Aborigines on northern stations were being mistreated, Ben Rogers wrote:

There are blacks on all the stations north of the Hergott, and they are treated far better than most of the whites by the Managers of stations; their work is light, chiefly fetching horses in the morning or some other light work. They are well fed, dressed well, and have plenty of time on their hands, so that they are a very lively people, and spend a great part of their time dancing and singing. You will see none of this at the mission station; quite the reverse, sulky miserable wretches, no life in them whatsoever, in fact they are nothing else but slaves, and the sooner this is altered the better it will be for blacks and whites. 1 am certain that if the missionaries had not interfered with the rites of the blacks they would have been far more peaceably inclined. ${ }^{73}$

71. SAGG, 12 February 1980, p 543.

72. McGrath 1987: 106, 158-9; Dawn May, 1994. Aboriginal labour and the cattle industry. Queensland from white settlement to the present, Cambridge, Pp 88-9.

73. South Australian Register, 2 April 1890. 
Unlike missionaries, pastoralists were not particularly concerned about how Aboriginal people lived their lives, as long as it did not interfere with the work on the station.

Not only did the conditions of pastoral leases permit Aboriginal people to continue their associations, it often suited the pastoralists that they were continued. The seasonal round of employment on stations in the north meant that there was usually a quiet time of the year, usually summer, and it was during this period that their Aboriginal employees often went off to attend ceremonies. A central Australian settler explained it this way:

The aboriginal must be free to come and go as he pleases. It will not matter to him how many papers are signed - when the spirit moves him he will take his departure, either to attend a ceremony or to have a spell in his own fashion. ${ }^{74}$

Another pastoralist, underlining the importance of this freedom, claimed that all but a few of the 'fairly civilised' Aborigines 'go away on a holiday during the summer months, when they occupy their time as of old in hunting, fishing, corroborreeing, and sleeping', but, he noted, they always returned when the cooler weather set in. ${ }^{75}$ Furthermore, if there were periods when the Aboriginal people in the camps were away hunting and gathering, these were times when wages did not have to be paid or rations distributed.

\section{Rations and coexistence}

While food was the basic ration, the government periodically distributed a range of other items, the most significant feature of which was that they were intended to assist Aborigines in exploiting traditional resources. To assist their fishing, the government distributed netting twine, fishing lines and fishing hooks as well as canoes or boats. These items were distributed at ration depots along the River Murray, the Coorong, in coastal regions, as well as in the Lake Eyre Basin. The canoes were not only intended for fishing but to assist Aboriginal people in accessing hard to get to terrestrial resources. As the issuer at Wellington noted in 1865:

The blacks cannot now procure bark canoes as they could in former years. The want of boats is very much felt at Wellington where the tribes are divided, living on both sides of the river; and in bad weather I have known the sick, aged and infirm to be almost starving for two or three days, because they had not a boat to come across and get their rations. The boats are also required for fishing and shooting; they cannot use their nets without the assistance of a boat, and they cannot cross the swamps and lagoons to shoot duck or swan except in a boat. The blacks on the Coorong are quite as bad if not worse off, as their living mainly depends on fishing and shooting. ${ }^{76}$

Canoes became a commonly distributed item: in 1874 alone, nineteen canoes were supplied at depots along the Murray and the Lakes. ${ }^{77}$

A similar logic prevailed when the issuer of rations at Innamincka, Mounted Constable Power, requested two canoes for the Aborigines of his district. Writing in Novem-

74. Adelaide Observer, 2 December 1899.

75. Report of the 1899 Select Committee, $\mathrm{p} 48$.

76. SAGG, 23 March 1865, p 266.

77. Ibid., 20 August 1874, p 1671. 
ber 1883, Power pointed out that the Aborigines' principal food in summer was fish, which they caught in 'waterholes on Cooper's Creek', but things were more difficult in winter, especially when the creek was flooded. Canoes, he argued, would 'enable them to cross and re-cross the creek in search of food'. The inability to get across the flooded creek also increased the temptation to interfere 'with the cattle who crowd thickly on the sandhills'. ${ }^{78}$ The upshot was that canoes would assist them in accessing the resources of the Cooper's Creek region and reduce the potential for conflict.

Axes and tomahawks were other items regularly distributed at ration depots throughout the colony, principally to assist in cutting firewood. While firewood was sometimes distributed at depots in the more established districts, it was cheaper for the government to provide people with the means of cutting their own. It was also acknowledged that tomahawks and axes were necessary to help cut and shape the materials with which they constructed their wurlies, or dwellings. ${ }^{79}$ The final category of items that were issued were cooking utensils and cutlery, notably quart pots, or 'billies', pannikins and spoons. All of the items discussed here were being distributed by the 1860 s and many were still being distributed on pastoral station in the 1960 s. The government, by distributing these items, was actively assisting Aborigines to support themselves from traditional resources.

\section{Pastoralists defend the status quo}

By the late nineteenth century, Aboriginal people were almost universally acknowledged as the principal source of labour in the pastoral industry. Their value, as such, was underpinned by the regular supply of government rations and their continued right to hunt and gather on pastoral lands. Pastoralists were well aware of this and, when a Bill was put before parliament in 1899 which threatened to undermine this equilibrium, pastoralists and their supporters successfully opposed it.

In 1899 South Australia's first, all-encompassing, Aborigines Bill was brought before parliament. Drafted by Justice Dashwood, it was modelled on the Queensland Aborigines Act of 1897. Dashwood was the Government Resident of the Northern Territory and freely admitted that the Bill was mainly designed to meet the frontier conditions of the South Australian-administered Northern Territory. ${ }^{80}$ The provisions of the Bill that caused the most controversy were those intended to regulate the employment of Aboriginal people. Clause 8 required that anyone employing Aboriginal people have a permit signed by the Protector, which would have to be renewed every twelve months. Clause 9 stipulated that every such employment agreement contain details of the nature of the employment, conditions of accommodation, remuneration, and so forth. Clause 10 provided for the Protector to supervise the conditions of employment. Clause 11 made it an offence to have Aborigines on, or about, one's premises, while Clause 12 made it an offence for Aborigines to be removed from their districts without permission. ${ }^{81}$

78.

79.

80. Gordon Reid, 1990. A picnic with the natives. Aboriginal-European relations in the Northern Territory to 1910. Melbourne, pp 163-70.

81. South Australian Parliamentary Debates, 12 July 1899, PP 32-3. 
When the Bill was debated in parliament, the first speaker, John Stirling, expressed the prevailing sentiments when he argued that it would have 'a deterrent effect on the useful employment of Aborigines in Central Australia'. The provision which made it illegal to have Aborigines about one's premises was strongly opposed. Stirling pointed out that it was the rule, rather than the exception, that Aborigines came onto the station and 'camped around them', but this provision would require him 'to get a licence for each of them'. The clause, he said, 'would certainly tend to drive the aborigines away from the stations' ${ }^{\prime}{ }^{82}$

Ebenezer Ward regarded it as part of a 'socialistic programme' to prevent lessees from employing black labour; the government, he said, 'would not allow the importation of Chinese, coolies, or kanakas, red, brown, or copper-colored laborers, and now even the blacks were to be disbarred'. ${ }^{83}$ The slippage in Ward's logic between indentured labour and Aboriginal labour is revealing. Coolies, he argued were the working strength of India: they may be superior to black labour, but 'those who were here before the whites had a right to be employed if they were willing to work'. ${ }^{84} \mathrm{How}$, he asked, would the Territory ever be developed without such labour?

John Warren expressed his surprise that, in the face of the leases which the pastoralists held, 'it should be proposed that the blacks must be driven off their country'. The leases ensured Aboriginal people's rights to be on pastoral lands:

Yet under the Bill lessees allowing natives on their premises would be guilty of an offence, unless they had obtained permits. If the Bill passed all the present leases would have to be withdrawn and fresh ones substituted. ${ }^{85}$

As Warren, like many of the opponents of the provisions pointed out, the nature of Aboriginal employment in the pastoral industry was often intermittent and task-oriented, and getting permits would be more trouble than it was worth. ${ }^{86}$

Frederick Basedow, while wanting to protect the Aborigines, agreed with the speakers who believed that the Act would have the effect of undermining Abroriginal employment and driving Aborigines from stations. He quoted a letter from Kempe, the Manager of Peake Station, who said he had an average of 68 Aborigines on his station, 30 of these were old and infirm and received government rations, while the remainder were employed 'as rabbiters, some as stockmen, etc.':

Should the proposed Bill become law the immediate effect on this run wrould be the discontinuance of the issue of Government rations (which are carted and issued to the aged and infirm blacks free by the station), and the discharge of the bulk of the blacks now employed in rabbiting etc., and under the harboring clause all unemployed blacks would have to be hunted off the run. ${ }^{87}$

In other words, not only would the provisions of the Bill undermine the existing labour relationships on the stations, the 'harbouring' provision would make it imposisible for stations to continue the practice of distributing rations on behalf of the government.

82. bid., $\mathrm{PP} 37-8$.

83. Ibid., PP 41-2.

84. Ibid., $\mathrm{P} 42$.

85. Ibid., $\mathrm{P} 57$.

86. Ibid.

87. Ibid., $\mathrm{P} 66$. 
A number of speakers pointed out that the provisions in the Bill were directly at variance with the conditions of their pastoral lease. Samuel Tomkinson, for instance, quoted a letter from the pastoralist Charles Davies who pointed out that he had 'employed as many of our natives as most people', and added:

I have always been under the impression that our blacks had a pre-emptive right to camp wherever they choose on the Crown lands if they do not interfere with the workings of the stations. It will be a sorry day for the blacks, especially for the Gawler Range ones, if the proposed Act is passed, and it might well be intituled 'An Act for the Prevention of the Employment of Aborigines'. 88

Objections on these issues saw the Bill referred to a Select Committee for further examination.

In the evidence presented during the Select Committee, pastoralists and their supporters continued to argue against the provisions relating to the employment of Aboriginal labour. Christopher Wade, for instance, pointed out the inconsistency between the conditions of their lease and the 'harbouring' clause. It was a 'cruel clause', he said, 'yet by our leases the aboriginal must not be disturbed' ${ }^{89}$ It was, he added, 'a Bill to deprive the nigger of his bread'. When it was pointed out to him that, as the law stood, 'a native can come up and sit by a spring and you have no power to order him off', he agreed and said that was what the leases provided, and if the proposed Act was introduced, he would be obliged to 'hunt the poor devils'. It would become a 'practical impossibility' to employ Aboriginal labour and it would almost certainly 'compel him to employ white labour. ${ }^{90}$ The pastoralist John Bagot also pointed out the inconsistency of the provisions with the conditions of their lease:

According to the conditions of our pastoral leases we are compelled to allow the blacks to camp without any let or hindrance at all natural waters, and permit them to engage in their ordinary pursuits of hunting wild animals. Under this clause, however, the blacks would have to be driven off from these places, and they would have no spot to go to at all. If they were driven off ... the Commissioner of Crown Lands could interfere on the ground that there was an infringement of the pastoral lease. ${ }^{91}$

When asked by the Chairman, 'Is that not a dead letter now?' he reiterated his point by saying, 'No; there is a provision in the pastoral lease that the blacks are not to be hunted'. ${ }^{92}$

Even some of the missionary supporters who had actively sought an Aborigines Act opposed this aspect of the Bill on the grounds that it would disrupt the labour relationships that were in place. Walter Dalton, the Secretary of the Aborigines Friends Association, said that he had been on sheep stations in the Port Lincoln district and had seen nothing but good relationships between Aboriginal people and their employers. He believed that no Aborigines would be employed if the clause was passed, and added, that while the existing relationship was of benefit to employers, it was of

\footnotetext{
88. Ibid., $\mathrm{p} 70$.

89. Report of the 1899 Select Committee, p 16.

90. Ibid., $\mathrm{P} 17$.

91. Ibid., p 40

92. Ibid.
} 
'greater advantage to the natives'. ${ }^{93}$ Not only were the provisions likely to deprive Aborigines of employment, but also of their traditional resources. Donald McLean, a Queensland pastoralist who had previously worked in South Australia, put it this way:

Take the outside country. The blackfellow knows where he can get good fishing and shooting, and so he comes to the waterhole at the station. I do not think it would be at all practicable to enforce this clause; it would be very unfair to the natives to keep them at a distance from the place where their natural instinct leads them to go and obtain food. ${ }^{94}$

McLean added, that the 'blacks have a claim on the country just as we have, and if we shut them out from our waterholes we are doing wrong' ${ }^{95}$

The Select Committee's report recommended the withdrawal of the Bill, and proposed a drastically watered-down alternative in which most of the restrictions on the employment of Aboriginal labour were removed. Instead of requiring employers to have licences for each of their Aboriginal employees, it recommended the issuing of certificates to 'reputable persons' authorising them to employ Aboriginal labour. The only labour provision that met their approval was the one prohibiting the removal of Aboriginal people from their districts 'unless stringent provisions' were made for their return.96

The Labor government responded by shelving the Bill. It was not until 1911 that South Australia passed its Aborigines Act. On this occasion the pastoralists had no objection to it because it contained no provisions that threatened the existing employment relationships in the pastoral industry. Sections 12 and 13 made it an offence to remove an Aboriginal person from his district without the authority of the Protector. Section 27 allowed a Protector or police to inspect the conditions in which Aboriginal people were employed, while Section 28 made it an offence to entice Aboriginal people away from their employment. The provisions pertaining to employment licences and 'harbouring', which the pastoralists had objected to so vehemently in 1899 , were omitted. ${ }^{97}$

\section{Conclusion}

The system of distributing rations to Aborigines on pastoral stations, complemented by the fact of Aboriginal rights on pastoral leases, facilitated the 'colonisation' of Aboriginal labour in the pastoral industry. The practice of distributing rations assisted pastoralists in securing and managing a source of labour that was cheap and skilled, and which they could draw upon when needed and release when surplus to demand. The fact of Aboriginal rights on pastoral leases meant that Aboriginal people not only could but were expected to rely on traditional resources when employment was unavailable. While pastoralists sometimes complained of the responsibilities of having Aboriginal people on their runs, and having to distribute rations, these factors nonetheless constituted a significant government subsidy to the cost of labour. Testimony to the value of

93. Ibid., $\mathrm{p} 43$.

94. Ibid., $\mathrm{P} 49$.

95. Ibid.

96. Ibid., p 5.

97. An Act to make provision for the better Protection and Control of the Aboriginal and Halfcaste Inhabitants of the State of South Australia, no. 1048 of 1911. 
this relationship, from the pastoralist's point of view, is that they successfully resisted attempts to change it and, coincidentally, were probably responsible for ensuring the preservation of coexistent rights on pastoral leases.

The benefits to the government were considerable because it constituted an exceptionally cheap and largely 'hands-off' form of administration. As long as pastoralists were willing and able to distribute rations, and Aboriginal people could continue living in, and off, their country, the government had no need to appoint additional protectors or police in the districts, nor establish government-supervised reserves. The government effectively made the employers of Aboriginal labour their guardians - the absence of any meaningful regulations controlling the nature of that employment might be regarded as their reward for this service. From an Aboriginal perspective, the consequences were mixed. In contrast to their southern brethren, who were increasingly concentrated on missions, Aboriginal people in pastoral districts were able to maintain traditional associations with their country, without the censorial control of missionaries. The offset to this was that private citizens, notably station managers, were handed considerable authority over the lives of those Aboriginal people on their stations.

The significance of the system that emerged - this balance between employment, rations and traditional resources on pastoral lands - is underscored by the fact that it endured for almost a hundred years. In its report for 1956, the Aborigines Protection Board explained the principles by which relief was distributed to 'necessitous Áborigines':

Supplementary rations are supplied to aborigines at many depots throughout the State. These rations are issued to almost all the natives including able-bodied, where they are not employed, and the aborigines are expected to hunt for native game to supply a large portion of their diet. This particularly applies to some detribalised or the near primitive natives and those residing on the pastoral areas. ${ }^{98}$

\section{Acknowledgements}

It was in conversations with Tom Gara that some of the ideas in this paper were originally developed. Thanks also to Bill Thorpe of Flinders University, and Mandy Paul formerly of the Central Land Council, for reading drafts of the paper and offering comments.

\section{References}

Aborigines Department, Correspondence Files, State Records GRG 52/1.

Aborigines Department, Ration Ledger Book, State Records GRG 52/25.

Adelaide Observer.

An Act to make provision for the better Protection and Control of the Aboriginal and Half-caste Inhabitants of the State of South Australia, no. 1048 of 1911.

Beltana Pastoral Company Records, Mortlock Library of South Australiana, BRG 133/36.

98. Report of the Aborigines Protection Board for the Year ended 30 th June, 1956, South Australian Parliamentary Papers, 1957, p 5. 
Brock, P, 1995. 'Pastoral stations and reserves in South and Central Australia, 1850s$1950 s^{\prime}$, in Ann McGrath, Kay Saunders with Jackie Huggins (eds), Aboriginal Workers. Special Issue of Labour History, no. 69, Sydney.

Colonial Secretary's Office, Correspondence files, State Records, GRG 24/6.

Crown Lands and Immigration Office, Correspondence files, GRG 35/1.

Donovan, Peter, 1995. 'In the interest of the county'. A history of the Pastoral Board of South Australia 1893-1993, Openbook Publishers, Adelaide.

Foster, R, 1989. 'Feasts of the full: the distribution of rations of Aborigines in South Australia: 1836-1861'. Aboriginal History 13(1): 63-78.

Foster, R, 1993. An imaginary dominion. The representation and treatment of Aborigines in South Australia, 1834-1911, PhD thesis, University of Adelaide.

Griffin, T and M McCaskill (eds), 1986. Atlas of South Australia. Adelaide.

Lease of Waste Land of the Crown of Michael Martin and John Bradford, South Australian Department of Lands, Pastoral Lease no. 226, 1 July 1951.

McGrath, A, 1987. 'Born in the cattle', Aborigines in the cattle industry. Sydney.

May, D, 1994. Aboriginal labour and the cattle industry. Queensland from white settlement to the present. Cambridge.

Reid, G, 1990. A picnic with the natives. Aboriginal-European relations in the Northerm Territory to 1910, Melbourne.

Report of the Pastoral Lands Commission, together with Minutes of Proceedings, Evidence and Appendices, South Australian Parliamentary Papers, no. 33 of 1891.

Report of the Protector of Aborigines for the Year Ending June 30, 1901, Government Printer, Adelaide, 1901.

Report of the Select Committee of the Legislative Council on the Aborigines Bill, together with minutes of Proceedings, South Australian Parliamentary Papers, no. 77 \& $77 \mathrm{a}$ of 1899.

Richards, E, 1986. 'The peopling of South Australia 1836-1986', in E Richards (ed.) The Flinders history of South Australia. Social history. Adelaide.

South Australian Government Gazette.

South Australian Parliamentary Debates.

South Australian Register.

Symons, Michael, 1982. One continuous picnic: a history of eating in Australia. Adelaide.

Thorpe, B, 1992. 'Aboriginal employment and unemployment: colonised labour', in C William and B Thorpe, Beyond industrial sociology: the work of men and women. Sydney, $\mathrm{p} 96$.

Tolcher, HM, 1986. Drought or deluge. Man in the Cooper's Creek region. Melbourne University Press.

Tunbridge, D, 1991. The story of the Flinders Ranges mammals. Kangaroo Press, Sydney. 